\title{
1 Nutritional Analysis of Sagebrush by Near-infrared Reflectance Spectroscopy
}

3 Peter J. Olsoy ${ }^{a}$, Thomas C. Griggs ${ }^{b}$, Amy C. Ulappa $^{a}$, Kristina Gehlken ${ }^{c}$, Lisa A. Shipley ${ }^{a}$,

4 Glenn E. Shewmaker ${ }^{d}$, and Jennifer Sorensen Forbey, ${ }^{c, *}$

5

6

$7 \quad{ }^{a}$ School of the Environment, Washington State University, Pullman, WA 99164, USA

$8{ }^{b}$ Division of Plant and Soil Sciences, West Virginia University, Morgantown, WV 26506, USA

$9{ }^{c}$ Department of Biological Sciences, Boise State University, Boise, ID 83725, USA

$10{ }^{d}$ Department of Plant, Soil, and Entomological Sciences, University of Idaho Kimberly Research

11 and Extension Center, Kimberly, ID 83341, USA

12

13 At the time of research, Peter J. Olsoy was a Research Associate, Dept of Biological Sciences,

14 Boise State University, Boise, ID 83725, USA.

15

16 Correspondence: Jennifer S. Forbey, Dept of Biological Sciences, Boise State University, Boise,

17 ID 83725, USA. Email: jenniferforbey@ boisestate.edu

18

19 Current Address: Jennifer S. Forbey, Dept of Biological Sciences, Boise State University, 1910

20 University Drive, Boise, ID 83725-1515. 
22 Sagebrush (Artemisia spp.) habitat in the Intermountain West is one of the most endangered

23 ecosystems in North America due, in part, to fire, climate change, and anthropogenic

24 disturbances. However, restoration efforts rarely consider the dietary quality of sagebrush that is

25 conserved or restored despite growing evidence that it is an influential parameter explaining

26 habitat use by many important wild and domestic herbivores. The objective of this study was to

27 evaluate the capacity of near-infrared reflectance spectroscopy (NIRS) to measure and monitor

28 the dietary quality of sagebrush. Leaf samples were collected from two sagebrush species over

29 two seasons and three sites in Idaho, USA. We developed calibration equations for crude protein

30 (CP), dry matter digestibility (DMD), 1,8-cineole (cineole), and total polyphenolics. The

31 coefficient of determination $\left(r^{2}\right)$ and ratio of performance to deviation (RPD) were 0.93 and 3.5

32 for CP, 0.83 and 1.8 for DMD, 0.64 and 1.5 for cineole, and 0.64 and 1.6 for total polyphenolics.

33 These results indicate that NIRS may offer a rapid, noninvasive, diagnostic tool for assessing

34 dietary quality of sagebrush, but future research should explore the potential for development of

35 improved prediction equations and in situ analysis of sagebrush dietary quality with field

36 spectroscopy.

38 Keywords: cineole, dietary quality, near-infrared reflectance spectroscopy, plant secondary 39 metabolites, polyphenolics, sagebrush

40

$41 \quad 1$. Introduction

42 Sagebrush (Artemisia spp. L.) dominates approximately 62 million ha of the western United

43 States (West and Young 2000), but is declining at an increasing rate, due, in part, to fire, climate 
44 change, and human activities (Meinke et al. 2009, Davies et al. 2011). Many herbivores eat

45 sagebrush, including wild ungulates (e.g., mule deer [Odocoileus hemionus], pronghorn

46 [Antilocapra americana], and elk [Cervus canadensis]) (Torstenson et al. 2006), livestock (e.g.,

47 sheep [Ovis aries]), and species that are of conservation concern (e.g., Gunnison sage-grouse

48 [Centrocercus minimus], greater sage-grouse [Centrocercus urophasianus], and pygmy rabbits

49 [Brachylagus idahoensis]). Herbivores select specific accessions or patches of sagebrush on the

50 landscape, and individual sagebrush plants within a patch are preferentially browsed by

51 herbivores (Behan and Welch 1985, Frye et al. 2013, Arkle et al. 2014). In many cases, a higher

52 concentration of crude protein $(\mathrm{CP})$ and lower concentration of plant secondary metabolites

53 (PSMs) such as monoterpenes and polyphenolics explain diet selection by herbivores (Frye et al.

54 2013, Ulappa et al. 2014). Therefore, land use and climate changes that affect the abundance and

55 dietary quality of sagebrush (Karban et al. 2006, Beck et al. 2012) can influence the use of

56 sagebrush by native herbivores and livestock for both cover (Camp et al. 2013) and food (Frye et

57 al. 2013, Ulappa et al. 2014).

59 In particular, changes in climate are expected to change not only the abundance and distribution

60 of sagebrush, but also the dietary quality of remaining sagebrush (Forbey et al. 2013). For

61 example, rises in $\mathrm{CO}_{2}$, ultraviolet light, temperatures, and drought are predicted to increase

62 concentrations of PSMs and decrease concentrations of CP (Robinson et al. 2012), reducing the

63 dietary quality of sagebrush for foraging herbivores. Rising temperatures also are predicted to

64 increase abundance of insects (Currano et al. 2010) that could increase defoliation of sagebrush.

65 Increased damage by insects limits the growth and reproduction of sagebrush (Takahashi and

66 Huntly 2010) and causes an induction of PSMs in sagebrush and surrounding plants through 
67 interplant volatile communication (Karban et al. 2000). Finally, PSMs are predicted to become

68 more toxic to herbivores with increasing temperatures (Forbey et al. 2013, Dearing 2013).

70 Although efforts to restore higher quality sagebrush habitats are increasing, these efforts rarely

71 consider how restoration and management activities may influence the dietary quality of

72 sagebrush. For example, most restoration efforts focus on planting Wyoming big sagebrush

73 (Artemisia tridentata subsp. wyomingensis Beetle \& Young) (McAdoo et al. 2013), and do not

74 also include planting of dwarf species such as black sagebrush (A. nova A. Nels.) and low

75 sagebrush (A. arbuscula Nutt.). However, Frye et al. (2013) showed that that black sagebrush

76 was selected by free-ranging sage-grouse over Wyoming big sagebrush when both species co-

77 occurred, and Rosentreter (2005) reported that these dwarf species were more nutritious for sage-

78 grouse and other herbivores. Furthermore, when sagebrush is reseeded after fire, survival is low

79 (Arkle et al. 2014) and the sagebrush that survives (McAdoo et al. 2013) may not include the

80 species preferred by herbivores. Other restoration efforts such as prescribed fires or application

81 of herbicides (Beck et al. 2012) often do not consider how these activities might influence the

82 dietary quality of remaining sagebrush. One reason for this oversight is that measuring and

83 monitoring the nutritional and chemical traits of plants is difficult to achieve over large

84 landscapes. Managers currently lack the tools necessary to measure dietary constituents at the

85 same spatial and temporal scales at which changes in habitat or management activities are

86 occurring. For example, measuring plant quality requires collecting many plant samples

87 throughout the year and detailed laboratory nutritional and PSM quantitative analysis, both of

88 which are prohibitively time-consuming and expensive. 
90 Management and restoration of sagebrush habitat may benefit from a rapid, predictive tool that

91 can assess dietary quality of sagebrush both in the lab and in the field and decrease plant sample

92 collection and processing tasks. One approach is the use of near-infrared reflectance

93 spectroscopy (NIRS) to measure plant constituents that define dietary quality for herbivores,

94 such as CP and PSM concentrations in plants (Foley et al. 1998, Roberts et al. 2004, Mitchell et

95 al. 2012, Youngentob et al. 2012). NIRS has been widely used in food science and agriculture to

96 predict CP (Abrams et al. 1987, Jensen et al. 2012), digestible energy (Abrams et al. 1987,

97 Griggs et al. 1999), monoterpenes (Steuer et al. 2001, Wilson et al. 2002), and polyphenolics

98 (Schulz et al. 1999, Flinn et al. 1996), among other dietary constituents that may be important to

99 herbivores. Therefore, NIRS provides a more rapid and potentially cost-efficient approach to

100 evaluate diet quality of specific species of sagebrush compared to laboratory methods (Foley et

101 al. 1998). Moreover, NIRS has the potential to help map the distribution of sagebrush species

102 with different chemical constituents at larger spatial scales (Clark and Roberts 2012). This ability

103 could help predict and monitor habitat use by herbivores, as was demonstrated in the koala

104 (Phascolarctos cinereus)/ eucalypt (Eucalyptus microcorys F. Muell.) system in Australia

105 (Moore et al. 2010). Further, knowledge of sagebrush dietary quality may allow managers to

106 prioritize conservation of higher quality sagebrush, or select seeds from these plants for

107 restoration following disturbances such as fire. Current laboratory instrumentation and

108 chemometrics software enable rapid and repeatable measurements of plant dietary quality. Field

109 spectroscopy for similar purposes is evolving and has not yet been implemented widely (Starks

110 and Brown 2010). Therefore, our study objectives were to evaluate NIRS with respect to its 1)

111 viability as a predictive tool of sagebrush dietary quality; and 2) accuracy of prediction of dietary 
112 quality with a single equation for two species (big sagebrush and black sagebrush) across three

113 study sites and two seasons.

114

115

116

\section{Methods and Materials}

\subsection{Study Sites}

117 We conducted research at three sites in Idaho, US. The “Camas" site (lat $44^{\circ} 14^{\prime} 28^{\prime}$ "N, long

$118114^{\circ} 19^{\prime} 04^{\prime \prime} \mathrm{W}$, elevation $1472 \mathrm{~m}$ ) is a 300 ha area located north of Shoshone, Idaho, in Lincoln

119 County. This site is dominated by Wyoming big sagebrush, but also includes low sagebrush.

120 During this winter study (October 2009 to March 2010), Camas had high temperatures averaging

$1212.6^{\circ} \mathrm{C}$, low temperatures averaging $-9.2^{\circ} \mathrm{C}$, and mean annual precipitation of $226 \mathrm{~mm}$. The

122 “Leadore” site (lat $44^{\circ} 41^{\prime} 57^{\prime}$ N, long $113^{\circ} 17^{\prime} 12^{\prime \prime} \mathrm{W}$, elevation $1942 \mathrm{~m}$ ) is a 225 ha area near

123 Leadore, Idaho, in Lemhi County, which is also dominated by Wyoming big sagebrush and

124 included black sagebrush. During our study, Leadore had high temperatures averaging $3.0^{\circ} \mathrm{C}$,

125 low temperatures averaged $-10.1^{\circ} \mathrm{C}$, and mean annual precipitation was $170 \mathrm{~mm}$. The main

126 browsing on sagebrush at the Camas and Leadore sites is by pygmy rabbits (see Ulappa et al.

127 2014). The "Browns Bench" site (lat $42^{\circ} 11^{\prime} 31^{\prime \prime} \mathrm{N}$, long $114^{\circ} 46^{\prime} 11^{\prime \prime} \mathrm{W}$, elevation 1550-1750 m)

128 is a 19000 ha area located in Twin Falls County in south central Idaho. This site is dominated

129 by black sagebrush, but also includes low sagebrush, hybrids between black and low sagebrush,

130 and Wyoming big sagebrush. During our study, Browns Bench had high temperatures averaging

$1318.1^{\circ} \mathrm{C}$, low temperatures averaged $-2.6^{\circ} \mathrm{C}$, and mean annual precipitation was $306 \mathrm{~mm}$. The main

132 browsing on sagebrush at the Browns Bench site is by sage-grouse (see Frye et al. 2013). 


\subsection{Sample Collection}

136 To obtain reference samples for NIRS calibration, we collected representative leaf samples from

137 individual sagebrush plants at all three sites in fall and winter, and additionally from the Camas

138 site in summer. We focused sampling in the winter to better capture nutritional quality when

139 sagebrush comprises up to 99\% of pygmy rabbits' diet (Shipley et al. 2006). At the Camas site,

140 leaf samples from Wyoming big sagebrush were collected in November $2009(n=50)$ and in

141 May and June $2010(n=54)$. At the Leadore site, leaf samples from Wyoming big sagebrush

142 were collected in October $2009(n=54)$. At the Browns Bench site, the collection of black

143 sagebrush leaf samples occurred in February and March $2010(n=22)$. Extra samples were

144 collected at the Camas site in May and June 2010 to test the effects of sample drying and particle

145 size and removal of spectral water regions on NIRS analysis (see Fig. S1 and Table S1, available

146 online). Those results showed that prediction accuracy of chemical composition of coarsely

147 ground samples (preparation described below) was better for dry than for wet material, and

148 similar among dry coarsely ground and finely-ground for CP but better for dry finely-ground

149 samples for total polyphenolics. We subsequently performed NIRS analyses with dry coarsely

150 ground samples.

\section{3. $\quad$ Sample Preparation and Nutritional Analysis}

153 To prepare sagebrush samples for nutritional analyses and NIRS, we separated leaves from stems

154 by freezing the samples with dry ice, dislodging the leaves, and then removing the stems, dead

155 leaves and debris. We then coarsely ground each sample in liquid nitrogen with a mortar and

156 pestle to an average particle size of approximately $2 \mathrm{~mm}$. Subsamples were taken for NIRS

157 analysis and for chemical analysis. A subsample was stored at $-20^{\circ} \mathrm{C}$ for monoterpene and total 
158 polyphenolic analysis while the remaining sample for chemical analysis was dried to constant

159 weight at $50^{\circ} \mathrm{C}$ to determine dry mass. The dried sample was analyzed for total $\mathrm{CP}$ and dry

160 matter digestibility (DMD). Digestibility was performed with an in vitro digestion assay

161 (DeGabriel et al. 2008, Ulappa et al. 2014) which subtracted average post-digestion dry matter

162 (DM) amounts from average pre-digestion DM to calculate DMD. We used the combustion

163 method (Dairy One Forage Labs, Ithaca, New York) to quantify protein concentration in

164 subsamples before (pre-digest sample) and after (post-digest sample) digestion.

165

166

2.4. Plant Secondary Metabolite Analysis

167 To obtain reference chemistry of PSMs for nutritional analysis and NIRS, we analyzed

168 monoterpene concentration of 1,8-cineole (cineole) of wet subsamples using gas

169 chromatography. For each sample $\sim 0.10 \mathrm{~g}$ (wet weight) of sample was extracted for $24 \mathrm{~h}$ at

170 room temperature in $1 \mathrm{~mL}$ of methylene chloride (HPLC grade) spiked with an internal standard

171 of fenchone ( > 98\% purity, CAS\# 4695-62-9, not naturally present in sagebrush samples) at a

172 concentration of $50 \mu \mathrm{g} \cdot \mathrm{mL}^{-1}$. We then dried each sample for $1 \mathrm{~h}$ with $0.25 \mathrm{~g}$ of anhydrous

173 sodium sulfate (granular). Extracts were removed, filtered through glass wool and processed by a

174 HP 7673 controller and sampled by a HP 6890 series II injector. Two $\mu \mathrm{L}$ of each sample were

175 injected into the HP 5890 series II gas chromatograph with flame ionization detector. The

176 stationary phase was a DB-5 Agilent silica column $(30 \mathrm{~m} \times 0.25 \mathrm{~mm})$ with a $0.25 \mu \mathrm{m}$ coating.

177 The initial oven temperature was $40^{\circ} \mathrm{C}$ for $2 \mathrm{~min}$, then increased at 3 degrees $\cdot \mathrm{min}^{-1}$ until

178 reaching $60^{\circ} \mathrm{C}$, then increased at 5 degrees $\cdot \min ^{-1}$ until $120^{\circ} \mathrm{C}$, and finally increased at 20

179 degrees $\cdot \min ^{-1}$ to $300^{\circ} \mathrm{C}$ and was held for $7 \mathrm{~min}$. Injector and detector temperatures were $250^{\circ} \mathrm{C}$

180 and $300^{\circ} \mathrm{C}$, respectively. The make-up and carrier gases were helium. The inlet pressure was 80 
$181 \mathrm{kPa}$ with a flow rate of $1.00 \mathrm{~mL} \cdot \mathrm{min}^{-1}$. Monoterpene retention times and peak areas were

182 calculated by HP ChemStation version B.01.00 and their identities were verified using co-

183 chromatography with standards. Monoterpene concentrations were expressed as $\mu \mathrm{g}$ of compound

184 in fenchone equivalents per $\mathrm{g}$ DM of plant sample $\left(\mu \mathrm{g} \cdot \mathrm{g}^{-1} \mathrm{DM}\right)$.

185

186 We analyzed total polyphenolic concentration of wet subsamples using a colorimetric assay

187 (Ainsworth and Gillespie 2007). Each sample was extracted in 95\% methanol for $24 \mathrm{~h}$. From the

188 supernatant, $50 \mu \mathrm{L}$ of sample was diluted 1:5 and then mixed with $200 \mu \mathrm{L}$ of Folin-Ciocalteu

189 reagent $(20 \%)$ and $800 \mu \mathrm{l}$ of $700 \mathrm{mM}$ sodium bicarbonate in distilled water. The color intensity

190 was immediately measured using a BioTek Synergy MX multi-mode plate reader (BioTek,

191 Winooski, Vermont) at an absorbance of $765 \mathrm{~nm}$ at room temperature. Values were expressed as

$192 \mu \mathrm{M}$ of compound in gallic acid equivalents per $\mathrm{g} \mathrm{DM}$ of plant sample $\left(\mu \mathrm{M} \cdot \mathrm{g}^{-1} \mathrm{DM}\right)$.

\subsection{NIRS Analysis}

195 To obtain NIRS spectra for calibration equations, we scanned dried subsamples with a scanning 196 monochromator (NIRSystems Model 5000, FOSS North America, Eden Prairie, MN). Paired

197 scans were averaged and absorbance spectra were recorded as the reciprocal log of reflectance $198(\log [1 / \mathrm{R}])$ at $2 \mathrm{~nm}$ increments over 1100-2498 $\mathrm{nm}$. We combined the samples from all three 199 sites in the winter with the summer samples from Camas into a single population to increase the 200 sample size and maximize inference across time (seasons), space (sites), and species. Mean 201 spectra for each sample population are shown in Figure 1. Calibration sets were paired with

202 laboratory measurements and spectral data of all samples $(n=180)$ for CP and total 203 polyphenolics, and of all winter samples from all three sites $(n=126)$ for DMD and cineole. A 
204 set of 20 randomly selected samples was removed from the calibration set for subsequent

205 external validation of the performance of prediction equations developed with the remaining

206 calibration samples (ASTM 2012) (Table 1).

207

208

209

210

211

212

Table 1. Descriptive statistics of lab-measured chemistry for calibration and validation data sets of crude protein (CP), dry matter digestibility (DMD), 1,8-cineole (cineole), and total polyphenolics. Leaf samples were pooled across three study sites (Camas, Leadore, and Browns Bench) in Idaho, US, two seasons (winter and summer), and two species (Wyoming big sagebrush [Artemisia tridentata subsp. wyomingensis Beetle \& Young] and black sagebrush [A. nova A. Nels.]).

\begin{tabular}{llrrrr}
\hline Constituent & Set & $\mathrm{n}$ & Range & Mean & SD \\
\hline $\mathrm{CP}$ & Calibration & 154 & $7.3-17.2$ & 12.2 & 1.64 \\
$\left(\% \mathrm{DM}^{1}\right)$ & Validation & 20 & $10.3-17.6$ & 12.8 & 1.79 \\
$\mathrm{DMD}$ & Calibration & 106 & $69.4-84.0$ & 76.7 & 2.44 \\
$(\% \mathrm{DM})$ & Validation & 20 & $68.7-84.7$ & 76.1 & 4.35 \\
$\mathrm{Cineole}$ & Calibration & 99 & $0-12627$ & 3519 & 3036 \\
$\left(\mu \mathrm{g} \cdot \mathrm{g}^{-1} \mathrm{DM}^{2}\right)$ & Validation & 20 & $473-14470$ & 4158 & 3720 \\
Total polyphenolics & Calibration & 154 & $33.8-189.7$ & 111.8 & 26.0 \\
$\left(\mu \mathrm{M} \cdot \mathrm{g}^{-1} \mathrm{DM}^{3}\right)$ & Validation & 20 & $58.8-248.4$ & 109.2 & 45.5 \\
\hline
\end{tabular}

$213{ }^{1}$ Units are in percent dry matter.

$214 \quad{ }^{2}$ Units are in $\mu \mathrm{g}$ of fenchone equivalents per g DM of plant sample.

$215 \quad{ }^{3}$ Units are in $\mu \mathrm{M}$ of gallic acid equivalents per $\mathrm{g} \mathrm{DM}$ of plant sample. 


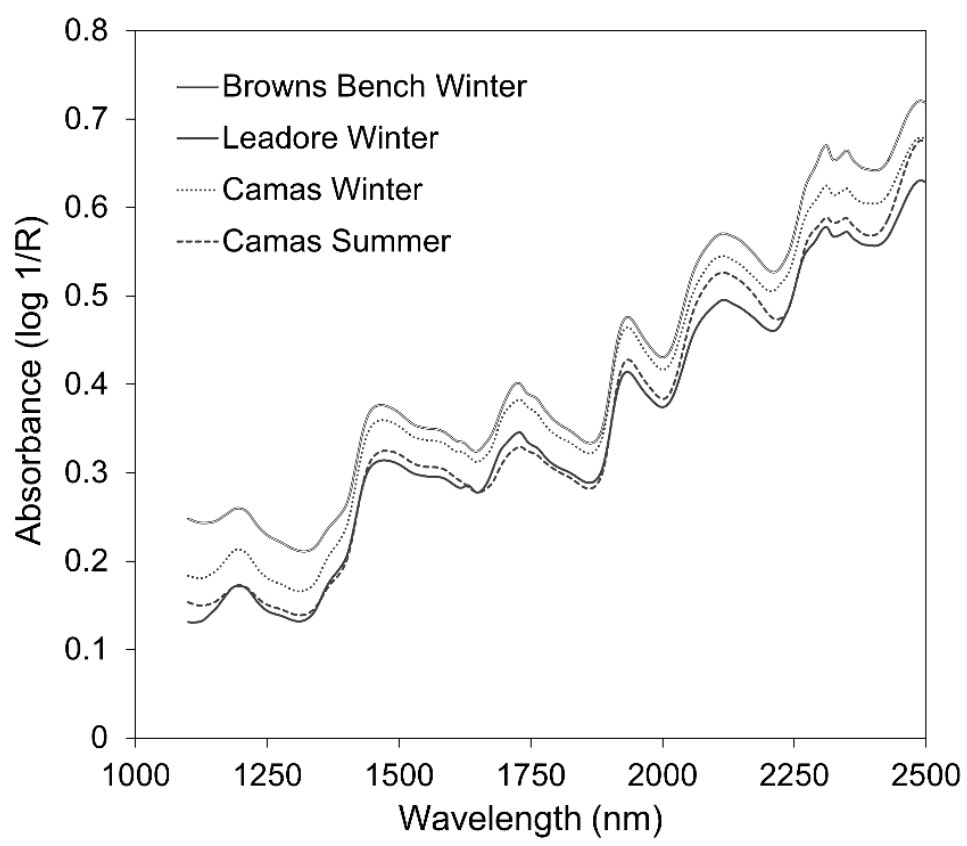

219 Fig. 1. Mean near-infrared reflectance spectra of samples of sagebrush leaves collected from two species (Wyoming 220 big sagebrush [Artemisia tridentata subsp. wyomingensis Beetle \& Young] and black sagebrush [A. nova A. Nels.]) 221 at three study sites (Camas, Leadore, and Browns Bench) in Idaho, US, over two seasons (winter and summer).

223 We determined relationships between compositional constituents and NIRS spectra according to 224 Shenk and Westerhaus (1991) with modified partial least squares regression using WinISI 4.5 225 chemometrics software (Infrasoft International LLC, State College, Pennsylvania). Prediction 226 equations were developed using every eighth wavelength over 1108-2492 nm following 1,4,4227 transformation of spectral data, representing the order of the derivative of raw spectral data and 228 numbers of 2-nm data points over which the derivative and a running smooth were calculated. 229 We used two outlier elimination passes and standard normal variate with detrending to reduce 230 variance associated with light-scattering effects. Internal cross-validation was used to calculate 231 standard error and coefficient of determination of cross-validation (SECV and 1-VR). The 20

232 external validation samples were used to calculate the standard error of validation (SEV), 233 coefficient of determination $\left(r^{2}\right)$, slope, and bias among predicted and actual laboratory reference 
234 values, and ratio of performance to deviation (RPD, calculated as standard deviation / SEV)

235 according to Williams (2001). Values of RPD $\geq 3$ indicate good predictive power.

\section{Results and Discussion}

238 Our evaluation indicates that CP of sagebrush forage can be estimated accurately with NIRS, but

239 DMD, cineole and total polyphenolics had lower prediction accuracy. We tested prediction

240 accuracy of NIRS relative to known laboratory values for CP, DMD, cineole, and total

241 polyphenolics. Externally-validated prediction accuracy was best for CP, which was the only

242 constituent to closely match the 1:1 line (Fig. 2A). Further, CP prediction equations had the

243 highest validation $r^{2}$ of 0.93 and the highest RPD of 3.5 (Table 2). The range in CP

244 concentration of 7.3-17.6\% in Wyoming big sagebrush leaves (Table 1) was wider than that

245 observed by Mitchell et al. (2012) for leaves of Wyoming and basin big sagebrush (A. t. Nutt.

246 subsp. tridentata) in Idaho, US. Welch and McArthur (1979) found mean CP for Wyoming big

247 sagebrush of 4 populations to be $11.8 \%$ in winter, which is similar to what we found in our 3

248 populations of Wyoming big sagebrush $(\overline{\mathrm{x}}=12.5 \%, \sigma=1.7)$. The results for $\mathrm{CP}$ compared

249 favorably with standard error of prediction (SEP) of 0.8 and RPD of 6.5 for CP from diverse

250 species of hay (Abrams et al. 1987), SEP of 1.0 and RPD of 3.6 for combined clipped timothy

251 (Phleum pratense L.). Results for CP also compared favorably with SECV of 0.8-1.2 and 1-VR

252 of $0.93-0.98$, for broad populations of forage grasses and legumes in equations used by

253 commercial forage testing laboratories (NIRS Forage and Feed Testing Consortium 2014) and

254 SECV of $0.6,1-\mathrm{VR}$ of 0.99 and RPD of 9.2 for 287 calibration samples of the shrub tagasaste

255 (Chamaecytisus proliferus (L. f.) Link; Flinn et al. 1996). Although our instrumentation and 
257 in 36 sagebrush samples, our calibration $R^{2}$ of 0.94 was slightly higher than their value of 0.86 .
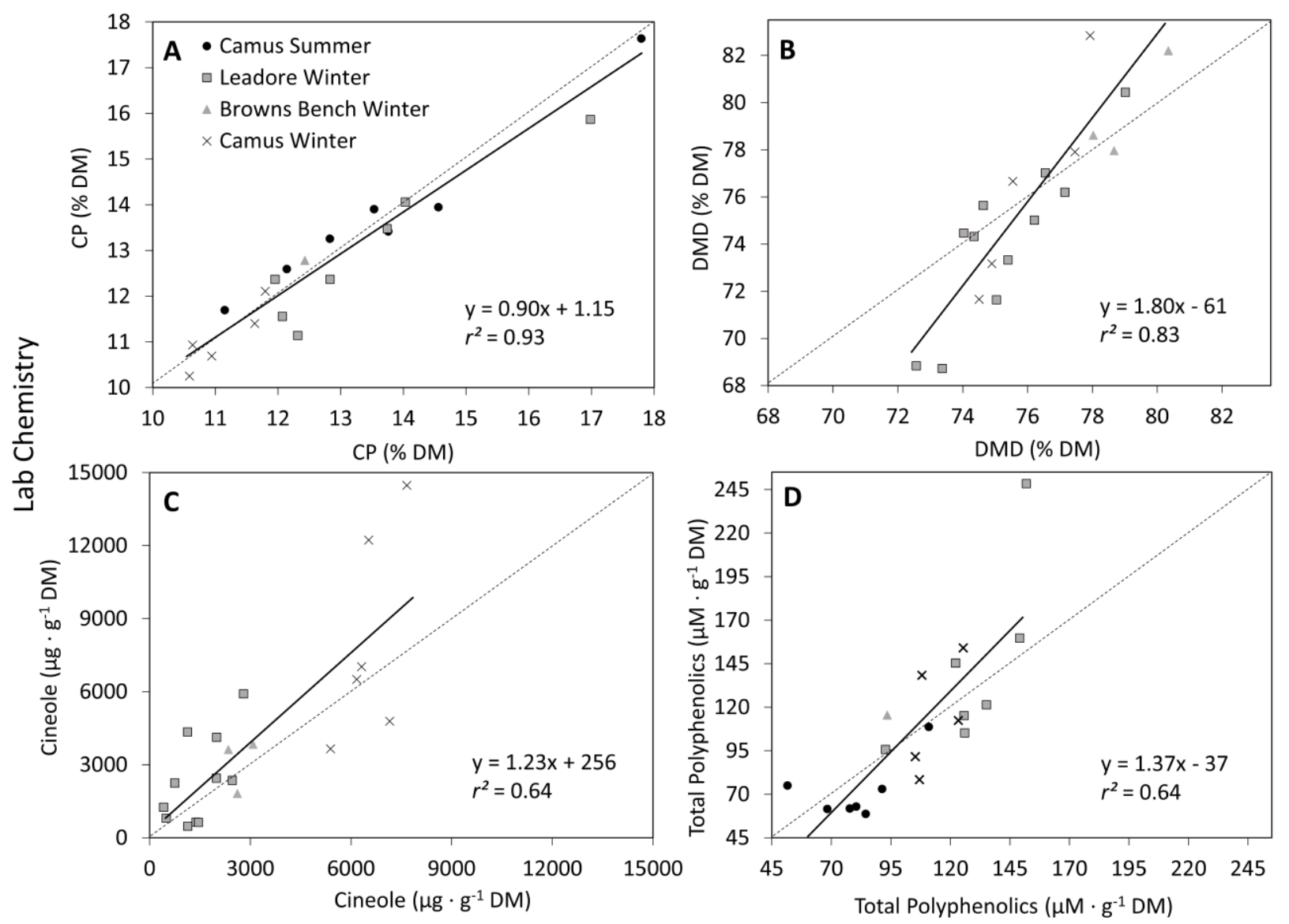

NIRS-Predicted Chemistry

259 Fig. 2. Validation graphs showing near-infrared reflectance spectroscopy-predicted (NIRS-predicted) nutritional

260 quality of sagebrush leaves regressed against lab-measured nutritional quality for A) crude protein (CP), B) dry

261 matter digestibility (DMD), C) 1,8-cineole, and D) total polyphenolics. Samples of two species (Wyoming big

262 sagebrush [Artemisia tridentata subsp. wyomingensis Beetle \& Young] and black sagebrush [A. nova A. Nels.])

263 were collected at three study sites (Camas, Leadore, and Browns Bench) in Idaho, US, during two seasons (winter

264 and summer). Dashed line indicates a 1:1 relationship, and solid line shows the validation regression fit. 
Table 2. Calibration and validation results for predicting the nutritional quality and chemistry of sagebrush using near-infrared reflectance spectroscopy. Leaf samples were pooled across three study sites (Camas, Leadore, and Browns Bench) in Idaho, US, two seasons (winter and summer), and two species (Wyoming big sagebrush [Artemisia tridentata subsp. wyomingensis Beetle \& Young] and black sagebrush [A. nova A. Nels.]).

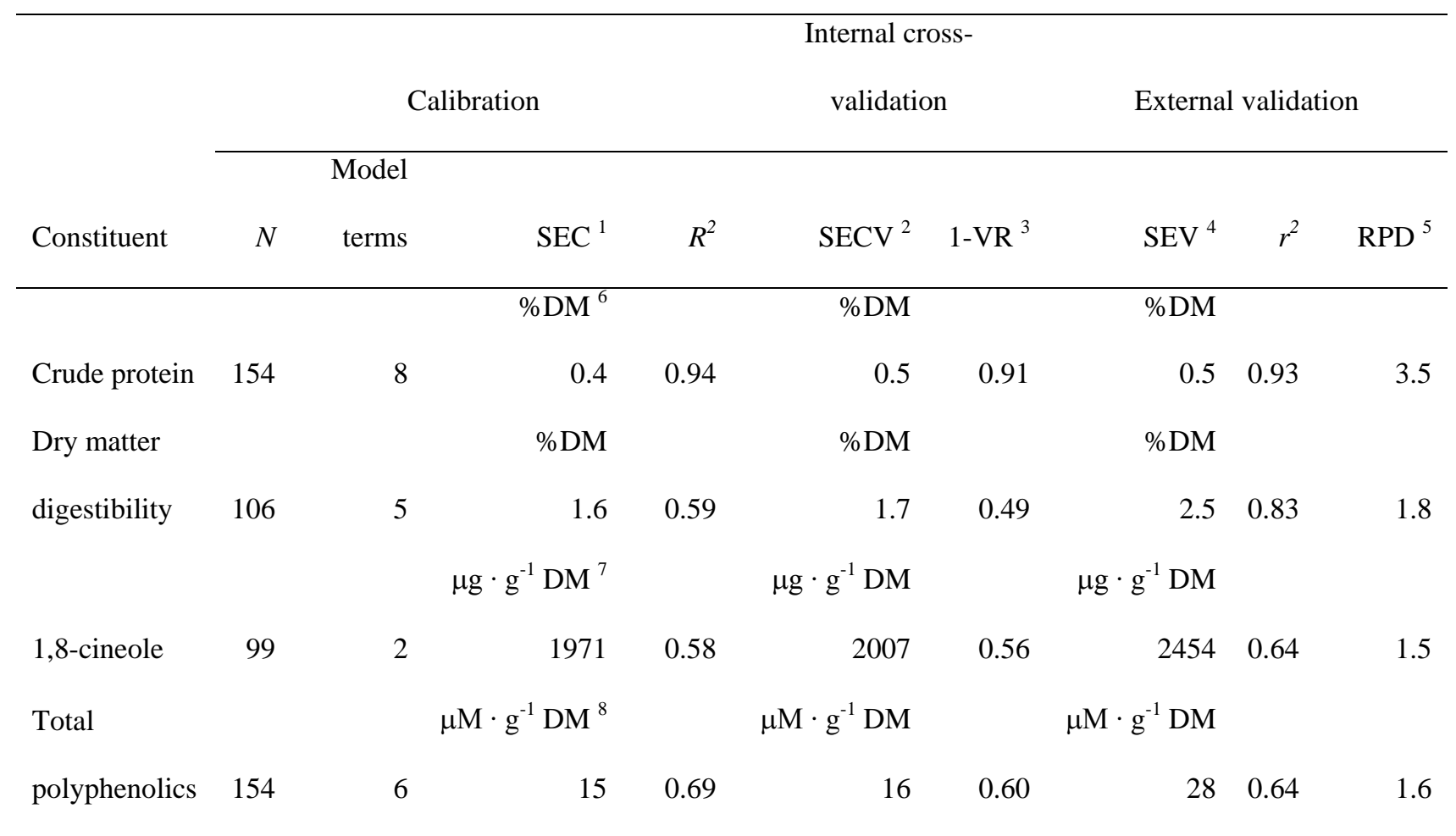

${ }^{1}$ Standard error of calibration.

$271 \quad{ }^{2}$ Standard error of cross-validation.

$272{ }^{3}$ Proportion of variation in laboratory values accounted for in cross-validation.

$273{ }^{4}$ Standard error of validation $(n=20)$.

$274{ }^{5}$ Ratio of performance to deviation, calculated as standard deviation of reference laboratory values / SEV.

$275{ }^{6}$ Units are in percent dry matter.

$276 \quad{ }^{7}$ Units are in $\mu \mathrm{g}$ of fenchone equivalents per g DM of plant sample.

$277{ }^{8}$ Units are in $\mu \mathrm{M}$ of gallic acid equivalents per g DM of plant sample.

280 Prediction accuracy for DMD was moderate with a validation $r^{2}$ of 0.83 and RPD of 1.8 (Table

281 2) and compared well with other studies, suggesting NIRS can reliably determine some forage

282 quality constituents. Results for DMD of SEV of 2.5 and validation $r^{2}$ of 0.83 were similar to

283 SECV of 1.6-3.1 and 1-VR of 0.85-0.95 from a variety of cool-season grasses and legume 
284 samples (Griggs et al. 1999), and SECV of 2.7-4.2 and 1-VR of 0.84-0.85 for forage grasses and

285 legumes in equations used by commercial forage testing labs (NIRS Forage and Feed Testing

286 Consortium 2014). Results for NIRS-predicted values also compared very favorably with SEP of

2873.0 for multiple species of hay (Abrams et al. 1987). Predictive strength of DMD from sagebrush

288 in this study as indicated by RPD of 1.8, however, was lower than the threshold of 3.0 suggested

289 by Williams (2001) and the value of 2.8 observed by Abrams et al. (1987) for hay, perhaps as a

290 function of differing reference methods or more variable particle size in our samples.

291

292 NIRS-predicted values for CP with SEV of 0.5 supported the ability of this approach to

293 distinguish between plants that are likely to be selected for browsing by animals and therefore

294 could be used for diet selection studies. Our coarsely-ground samples may have greater particle

295 size heterogeneity than is suggested by a mean particle size of $\sim 2 \mathrm{~mm}$. As indicated in our

296 supplemental data (Fig. S1 and Table S1, available online) and also found by Griggs et al.

297 (1999), accuracy of NIRS predications would likely improve for DMD if samples were more

298 finely ground and dried before analysis.

299

300 Predictive strength for total polyphenolics and cineole by NIRS was weaker than for CP and 301 DMD with validation $r^{2}$ of 0.64 , and RPD values of 1.6 and 1.5 , respectively (Table 2). RPD 302 values less than 3.0 suggest poor predictive ability (Williams 2001) and that NIRS may be more 303 appropriate for preliminary screenings of sagebrush samples than for quantitative analysis of 304 DMD, total polyphenolics, and cineole. Both cineole and total polyphenolics under-predicted 305 samples with high PSM concentrations (Figs. 2C and 2D), suggesting the calibration models do 306 not capturing all of the variation at the higher end. One potential reason for the lower accuracy in 
307 cineole prediction is that monoterpenes are volatile and thus lost during the process of drying

308 samples prior to NIRS. Another possible reason is the limited ability of NIRS to detect

309 concentrations of constituents below 0.1-1.0\% (Westerhaus et al. 2004). However, in other

310 studies, NIRS accurately predicted monoterpene concentrations in dried samples (Steuer et al.

311 2001, Wilson et al. 2002). This discrepancy may be caused by a larger sample size in other

312 studies, or because some monoterpenes may be correlated with other non-volatile chemical

313 attributes that can be detected by NIRS. In systems where these volatile chemicals are important,

314 we recommend analyzing wet samples. However, this is a tradeoff because scanning wet samples

315 could reduce prediction accuracy by NIRS (see Fig. S1 and Table S1, available online), because

316 water absorption bands may obscure important spectral peaks related to proteins and other

317 chemicals (Griggs et al. 1999).

319 The strength of predicting total polyphenolics with NIRS was similar to that found in other 320 studies. Our results of 0.60 and 1.6 for 1-VR and RPD were similar to that reported by Schulz et

321 al. (1999) in green tea (Camellia sinensis (L.) Kuntze) leaves where values for 1-VR and RPD

322 were 0.67 and 1.7, and much lower than reported by Goodchild et al. (1998) in annual legume

323 hays and straws for 1-VR and RPD of 0.95 and 4.5. Statistics from this latter study were based

324 on a limited calibration set of 39 samples and 8 model terms, however, which suggests model

325 overfitting. In a study with a calibration set of 227 samples, Flinn et al. (1996) were able to

326 predict total polyphenolics in tagasaste plants with 1-VR of 0.96 and RPD of 4.7. The reference

327 method for total polyphenolics in this case was a modification of one of the procedures of Price

328 and Butler (1977), which includes a spectrophotometric measurement following treatment with 
$329 \mathrm{FeCl}_{3} / \mathrm{K}_{3} \mathrm{Fe}(\mathrm{CN})_{6}$. Our results may reflect a limited sensitivity of our colorimetric reference

330 method for analysis of total polyphenolics, as suggested by Schulz et al. (1999).

332 Individual polyphenolic compounds such as coumarins fluoresce under UV light, and are

333 predicted to be indicators of more palatable sagebrush for wildlife (Rosentreter 2005). Isolating

334 individual polyphenolic compounds, or classes of polyphenolics with known fluorescence, in 335 addition to increasing the sample size, may improve NIRS prediction accuracy of polyphenolics,

336 particularly those related to diet selection, and should be evaluated in future research. NIRS

337 could be used to classify subspecies or hybridized morphotypes of sagebrush that vary in their

338 fluorescence (McArthur et al. 1988). Furthermore, NIRS can be used to holistically evaluate

339 palatability for wildlife (Moore et al. 2010), therefore reducing the need for relatively more

340 costly lab analyses.

341

342 Predicted values of CP and DMD seem to be independent of site (Figs. 2A and 2B), whereas

343 NIRS-derived equations for cineole and polyphenolics seem to be heavily affected by site (Figs.

344 2C and 2D) and may not be able to distinguish site-level differences in some PSMs. This site-

345 dependence is clearest in the cineole predictions where Camas winter samples are mostly

346 overestimated, whereas predictions for Leadore winter samples are largely underestimated (Fig.

347 2C). Additionally, higher PSM concentrations were underestimated with NIRS. The NIRS model

348 could not distinguish between samples with lab values of 6 000-15000 $\mu \mathrm{g} \cdot \mathrm{g}^{-1} \mathrm{DM}$ cineole, and

349 predicted those samples to be between 6 000-7 $000 \mu \mathrm{g} \cdot \mathrm{g}^{-1} \mathrm{DM}$. Further, where total

350 polyphenolics were high at Leadore in winter, samples with $145-245 \mu \mathrm{M} \cdot \mathrm{g}^{-1} \mathrm{DM}$ total

351 polyphenolics were not discriminated from each other with NIRS. Removing the largest outlier 
$352\left(>200 \mu \mathrm{M} \cdot \mathrm{g}^{-1} \mathrm{DM}\right)$ improved the slope from 1.37 to 1.04 , but the validation $r^{2}$ remained 0.64.

353 Researchers and managers should be careful about predicting samples with extreme values (i.e.,

354 very high PSM concentrations) without sufficient reference samples to effectively train the

355 calibration equations. Increasing the sample size of the calibration set may improve prediction

356 accuracy by more completely representing all sources of variation (ISO 2010).

\section{Conclusions}

359 This study demonstrates that NIRS can predict dietary constituents, specifically crude protein, of

360 sagebrush important to many wild and domestic herbivores. The application of NIRS to predict

361 nutrients and chemicals in sagebrush or other plants requires an initial investment in

362 instrumentation (cost range \$45 000-100 000) and initial quantification of actual PSMs of

363 interest from typically $\geq 120$ samples in the laboratory $\left(\sim \$ 6-10\right.$ sample $^{-1}$ for CP and $\$ 2-3$

364 sample $^{-1}$ for each PSM). However, after the predictive equations have been established and 365 validated, analysis of vegetation by NIRS offers a faster and cheaper measure of diet quality 366 compared to laboratory analysis. NIRS instruments are becoming increasingly available in the

367 agricultural industry and therefore offer researchers greater opportunity to collaborate with

368 industry to apply NIRS to other systems. Moreover, portable NIRS or other validated techniques

369 for field spectral analysis may allow researchers to scale up analysis of diet quality to habitats

370 and landscapes (Curran 1989, Goetz 2009, Kokaly et al. 2009). Much like geographic

371 information systems have been used to locate and map areas of the sagebrush landscape that

372 deserve the highest priority for conservation (Meinke et al. 2009), the development of NIRS to

373 quantify nutrients and PSMs has the potential to locate, map, and allow managers to prioritize

374 areas with sagebrush of higher food quality or select seeds from these plants for propagation 
375 following disturbance such as fire. NIRS provides great potential to map important dietary

376 variables across the landscape, calibrated for the variable of interest (Foley et al. 1998, Ebbers et

377 al. 2002), for a more complete picture of dietary factors driving landscape use by wild and

378 domestic species.

379

380 NIRS can also be used to identify thresholds of nutrients and chemicals that influence habitat use

381 by herbivores. These thresholds can then be used to identify the most palatable species or patches

382 of sagebrush that might deserve additional protection with respect to road development, fire

383 suppression, location of water troughs, energy development and other disturbances. Results offer

384 an encouraging first step that supports the feasibility of laboratory NIRS analysis and potential

385 field spectral analysis of the dietary quality of sagebrush across species, sites, and seasons.

386 However, more sampling is required to predict more complex PSMs such as cineole and total

387 polyphenolics, particularly of plants with extreme values. Further development of NIRS may

388 provide land managers with a powerful tool for assessing and conserving critical habitats

389 containing sagebrush that is the highest quality food for wild and domestic species.

390

391

ACKNOWLEDGEMENTS

We thank Dr. Janet L. Rachlow for helpful comments on a draft of this paper and for

393 access to the Leadore site. Research was funded in part by Boise State University, Washington

394 State University, Idaho Department of Fish and Game, the Bureau of Land Management, the

395 National Science Foundation (DEB-1146194 and IOS-1258217 to J.S.F., and DEB-1146368 to

396 L.A.S.), and the USDA National Institute of Food and Agriculture (Hatch Project 1005876). 
Abrams, S. M., J. S. Shenk, M. O. Westerhaus, and F. E. Barton. 1987. Determination of forage quality by near infrared reflectance spectroscopy: efficacy of broad-based calibration equations. Journal of Dairy Science 70:806-813.

401

Ainsworth, E. A., and K. M. Gillespie. 2007. Estimation of total phenolic content and other oxidation substrates in plant tissues using Folin-Ciocalteu reagent. Nature Protocols 2:875-877.

Arkle, R. S., D. S. Pilliod, S. E. Hanser, M. L. Brooks, J. C. Chambers, J. B. Grace, K. C. Knutson, D. A. Pyke, J. L. Welty, and T. A. Wirth. 2014. Quantifying restoration effectiveness using multi-scale habitat models: implications for sage-grouse in the Great

ASTM. 2012. ASTM E1655-05: Standard practices for infrared multivariate quantitative analysis. ASTM, West Conshohocken, PA.

Beck, J. L., J. W. Connelly, and C. L. Wambolt. 2012. Consequences of treating Wyoming big sagebrush to enhance wildlife habitats. Rangeland Ecology \& Management 65:444-455.

Behan, B., and B. L. Welch. 1985. Black sagebrush - mule deer winter preference and monoterpenoid content. Journal of Range Management 38:278-280.

Camp, M. J., J. L. Rachlow, B. A. Woods, T. R. Johnson, and L. A. Shipley. 2013. Examining

Clark, M. L., and D. A. Roberts. 2012. Species-level differences in hyperspectral metrics among tropical rainforest trees as determined by a tree-based classifier. Remote Sensing 4:18201855. 
420 Curran, P. J. 1989. Remote sensing of foliar chemistry (review). Remote Sensing of Environment $421 \quad 30: 271-278$.

422 Currano, E. D., C. C. Labandeira, and P. Wilf. 2010. Fossil insect folivory tracks

423 paleotemperature for six million years. Ecological Monographs 80:547-567.

424 Davies, K. W., C. S. Boyd, J. L. Beck, J. D. Bates, T. J. Svejcar, and M. A. Gregg. 2011. Saving 425 the sagebrush sea: an ecosystem conservation plan for big sagebrush plant communities. $426 \quad$ Biological Conservation 144:2573-2584.

427 Dearing, M. D. 2013. Temperature-dependent toxicity in mammals with implications for 428 herbivores: a review. Journal of Comparative Physiology B 183:43-50.

429 DeGabriel, J. L., I. R. Wallis, B. D. Moore, and W. J. Foley. 2008. A simple, integrative assay to 430 quantify nutritional quality of browses for herbivores. Oecologia 156:107-116.

431 Ebbers, M. J. H., I. R. Wallis, S. Dury, R. Floyd, and W. J. Foley. 2002. Spectrometric prediction of secondary metabolites and nitrogen in fresh Eucalyptus foliage: towards remote sensing of the nutritional quality of foliage for leaf-eating marsupials. Australian Journal of Botany 50:761-768.

435 Flinn, P. C., N. J. Edwards, C. M. Oldham, and D. M. McNeill. 1996. Near infrared analysis of 436 The future waves. NIR Publications, Chichester, UK. p. 576-580.

439 Foley, W. J., A. McIlwee, I. Lawler, L. Aragones, A. P. Woolnough, and N. Berding. 1998. 440 Ecological applications of near infrared reflectance spectroscopy a tool for rapid, costeffective prediction of the composition of plant and animal tissues and aspects of animal 442 performance. Oecologia 116:293-305. 
443 Forbey, J. S., N. L. Wiggins, G. G. Frye, and J. W. Connelly. 2013. Hungry grouse in a warming world: Emerging risks from plant chemical defenses and climate change. Wildlife Biology $19: 374-381$.

446 Frye, G. G., J. W. Connelly, D. D. Musil, and J. F. Forbey. 2013. Phytochemistry predicts habitat selection by an avaian herbivore at multiple spatial scales. Ecology 94:308-314.

448 Goetz, A. F. H. 2009. Three decades of hyperspectral remote sensing of the Earth: A personal view. Remote Sensing of Environment 113:S5-S16.

450

451

452

453

454

455

456

457

458

459

460

461

462

463

464

Goodchild, A. V, F. J. El Haramein, A. Abd El Moneim, H. P. S. Makkar, and P. C. Williams. 1998. Prediction of phenolics and tannins in forage legumes by near infrared reflectance. Journal of Near Infrared Spectroscopy 6:175-181.

Griggs, T. C., K. B. Lobos, and P. E. Kingery. 1999. Digestibility analysis of undried, unground, and dry ground herbage by near-infrared reflectance spectroscopy. Crop Science 39:1164-1170.

International Organization for Standardization (ISO). 2010. Animal feeding stuffs, cereals and milled cereal products - Guidelines for the application of near infrared spectrometry. ISO 12099. Geneva, Switzerland.

Jensen, K. B., I. W. Mott, J. G. Robins, B. L. Waldron, and M. Nelson. 2012. Genetic improvement and diversity in Snake River wheatgrass (Elymus wawawaiensis) (Poaceae: Triticeae). Rangeland Ecology \& Management 65:76-84.

Karban, R., I. T. Baldwin, K. J. Baxter, G. Laue, and G. W. Felton. 2000. Communication between plants: induced resistance in wild tobacco plants following clipping of neighboring sagebrush. Oecologia 125:66-71. 
Karban, R., K. Shiojiri, M. Huntzinger, and A. C. McCall. 2006. Damage-induced resistence in sagebrush: volatiles are key to intra- and interplant communication. Ecology 87:922-930.

467 Kokaly, R. F., G. P. Asner, S. V Ollinger, M. E. Martin, and C. A. Wessman. 2009.

468 Characterizing canopy biochemistry from imaging spectroscopy and its application to

469 ecosystem studies. Remote Sensing of Environment 113:S78-S91.

470 McAdoo, J. K., C. S. Boyd, and R. L. Sheley. 2013. Site, competition, and plant stock influence

471 transplant success of Wyoming big sagebrush. Rangeland Ecology \& Management

472 $66: 305-312$.

473 McArthur, E. D., B. L. Welch, and S. C. Sanderson. 1988. Natural and artificial hybridization between big sagebrush (Artemisia tridentata) subspeces. Journal of Heredity 79:268-

475 276.

476 Meinke, C. W., S. T. Knick, and D. A. Pyke. 2009. A spatial model to prioritize sagebrush 477 landscapes in the Intermountain West (USA) for restoration. Restoration Ecology $17: 652-659$.

479 Mitchell, J. J., N. F. Glenn, T. T. Sankey, D. R. Derryberry, M. O. Anderson, and R. C. Hruska.

480 2012. Spectroscopic detection of nitrogen concentrations in sagebrush. Remote Sensing Letters 3:285-294.

482 Moore, B. D., I. R. Lawler, I. R. Wallis, C. M. Beale, and W. J. Foley. 2010. Palatability mapping: A koala's eye view of spatial variation in habitat quality. Ecology 91:31653176.

485 NIRS Forage and Feed Testing Consortium. 2014. Available at: http://nirsconsortium.org. 486 Accessed 21 March 2014. 
Price, M. L., and L. G. Butler. 1977. Rapid visual estimation and spectrophotometric determination of tannin content of sorghum grain. Journal of Agricultural and Food Chemistry 25:1268-1273.

Roberts, C. A., J. Stuth, and P. Flinn. 2004. Analysis of forages and feedstuff. In: C. A. Roberts, J. Workman Jr, and J. B. Reeves III [eds.]. Near-infrared spectroscopy in agriculture. American Society of Agronomy, Madison, Wisconsin. p. 231-267.

Robinson, E. A., G. D. Ryan, and J. A. Newman. 2012. A meta-analytical review of the effects of elevated $\mathrm{CO} 2$ on plant-arthropod interactions highlights the importance of interacting environmental and biological variables. New Phytologist 194:321-336.

Rosentreter, R. 2005. Sagebrush identification, ecology, and palatability relative to sage-grouse. In: N. L. Shaw, S. B. Monsen, M. Pellant [comps.]. Sagegrouse Habitat Restoration Symposium Proceedings; June 4-7 2001; Boise, ID, USA. Proceedings RMRS-P-000. Fort Collins, CO: U.S. Department of Agriculture, Forest Service, Rocky Mountain Research Station. USDA Forest Service Proceedings.

Schulz, H., U. H. Engelhardt, A. Wegent, H. H. Drews, and S. Lapczynski. 1999. Application of near-infrared reflectance spectroscopy to the simultaneous prediction of alkaloids and phenolic substances in green tea leaves. Journal of Agricultural and Food Chemistry 47:5064-5067.

Shenk, J. S., and M. O. Westerhaus. 1991. Population structuring of near infrared spectra and modified partial least squares regression. Crop Science 31:1548-1555.

Shipley, L. A., T. B. Davila, N. J. Thines, and B. A. Elias. Nutritional requirements and diet choices of the pygmy rabbit (Brachylagus idahoensis): a sagebrush specialist. Journal of Chemical Ecology 32:2455-2474. 
510 Starks, P. J., and M. A. Brown. 2010. Prediction of forage quality from remotely sensed data:

511 comparison of cultivar-specific and cultivar-independent equations using three methods

512 of calibration. Crop Science 50:2159-2170.

513 Steuer, B., H. Schulz, and E. Lager. 2001. Classification and analysis of citrus oils by NIR $514 \quad$ spectroscopy. Food Chemistry 72:113-117.

515 Takahashi, M., and N. Huntly. 2010. Herbivorous insects reduce growth and reproduction of big $516 \quad$ sagebrush (Artemisia tridentata). Arthropod-Plant Interactions 4:257-266.

517 Torstenson, W. L. F., J. C. Mosley, T. K. Brewer, M. W. Tess, and J. E. Knight. 2006. Elk, mule 518 deer, and cattle foraging relationships on foothill and mountain rangeland. Rangeland $519 \quad$ Ecology and Management 59:80-87.

520 Ulappa, A. C., R. G. Kelsey, G. G. Frye, J. L. Rachlow, L. A. Shipley, L. Bond, X. Pu, and J. S. 521 Forbey. 2014. Plant protein and secondary metabolites influence diet selection in a 522 mammalian specialist herbivore. Journal of Mammalogy 95:834-842.

523 Welch, B. L., and E. D. McArthur. 1979. Variation in winter levels of crude protein among 524 Artemisia tridentata subspecies grown in a uniform garden. Journal of Range $525 \quad$ Management 32:467-469.

526 West, N. E. and J. A. Young. 2000. Intermountain valleys and lower mountain slopes. In:

527 Barbour, M. G. and W. D. Billing. [eds.]. North American terrestrial vegetation. 528 Cambridge, United Kingdom Cambridge University Press. 255-284.

529 Westerhaus, M., J. Workman, Jr., J. B. Reeves III, and H. Mark. 2004. Quantitative analysis. In: 530 C. A. Roberts, J. Workman Jr, and J. B. Reeves III [eds.]. Near-infrared spectroscopy in 531 agriculture. American Society of Agronomy, Madison, Wisconsin. p. 133-174. 
532 Williams, P. C. 2001. Implementation of near infrared technology. In: P. C. Williams and K. H.

533 Norris [eds.]. Near-infrared technology in the agricultural and food industries. 2nd

534 edition. American Association of Cereal Chemists, St Paul, MN. p. 145-171.

535 Wilson, N. D., M. S. Ivanova, R. A. Watt, and A. C. Moffat. 2002. The quantification of citral in 536 lemongrass and lemon oils by near-infrared spectroscopy. Journal of Pharmacy and

$537 \quad$ Pharmacology 54:1257-1263.

538 Youngentob, K. N., L. J. Renzullo, A. A. Held, X. P. Jia, D. B. Lindenmayer, and W. J. Foley. 539 2012. Using imaging spectroscopy to estimate integrated measures of foliage nutritional $540 \quad$ quality. Methods in Ecology and Evolution 3:416-426. 